Acta Poloniae Historica

113, 2016

PL ISSN 0001-6892

\title{
Grzegorz Skrukwa
}

Institute of Eastern Studies, Adam Mickiewicz University, Poznań

\section{'MASTERS OF SITUATION': \\ GERMAN AND AUSTRO-HUNGARIAN INTERVENTION \\ IN UKRAINE IN 1918 IN THE LIGHT \\ OF UKRAINIAN MEMOIRS}

\begin{abstract}
The article discusses the image of the German and Austro-Hungarian intervention in Ukraine in 1918 in Ukrainian memoirs. While these works generally describe the policies of the Central Powers toward Ukraine as imperialist and dictated by the military and economic interests of the two states, only the most radical leftist writers fail to appreciate the role German and Austrian troops played in the removal of Bolshevik forces from Ukraine. Common and individual portraits of the military and political apparatus of the intervention forces differ depending on the political position of the writer. Those who viewed the repressive policies toward rural Ukraine from the perspective of the elites of Kiev discuss them only in abstract terms. In general, Austro-Hungary's part in the intervention is described in less favourable terms than that of Germany.
\end{abstract}

Keywords: Ukraine, First World War, Germany, Austro-Hungary, occupation, intervention, memoirs, Treaty of Brest

During the Great War, Ukraine was the greatest country under occupation by the Central Powers, though, outside of its westernmost regions, the occupation lasted shorter than in Belgium, the Kingdom of Poland, or Serbia. While the forces of the Central Powers entered the territories of the Russian Empire inhabited by its Ukrainian population in 1915, until early 1918, the extent of the occupation zone in Ukrainian territories was limited to western Volhynia. ${ }^{1}$

${ }^{1}$ The Central Powers also extended control over areas that the Ukrainian national movement claimed as being of secondary interest - Podlachia, the Chełm/ Kholm district, and Polesia, disputed with Polish and, in part, Belarusian national movements. On the image of German policies toward these territories in Ukrainian memoirs, see: Вол[одимир] Куровський, 'На окупованич Німцями землях 
The sovereign state of Ukraine made its début in world politics after the disintegration of the Russian Empire. Following the February Revolution of 1917, the Ukrainian Central Rada (UCR) was established in Kiev, initially as a coordinating body of the national movement that later transformed into an actual preliminary parliament of Ukraine. In June 1917 the executive arm of the Central Rada, the Secretariat General, became the official government of an autonomy composed of the western and central governorates of Ukraine. On 20 November 1917, in response to the Bolshevik coup, Central Rada proclaimed the Ukrainian People's Republic (UNR) as part of the proposed Russian Democratic Federation. ${ }^{2}$ Yet, a Bolshevik invasion in January 1918 prompted the proclamation of Ukrainian People's Republic as a fully independent and sovereign state on 25 January 1918. ${ }^{3}$ The Central Rada, and, by extension, the Ukrainian People's Republic, was led by parties of the left, primarily the Ukrainian Social-Democratic Workers' Party and the Ukrainian Party of Socialist Revolutionaries - forces ideologically distant from the imperial governments of Berlin and Vienna.

On 9 February 1918 the UNR concluded a peace treaty with the Central Powers in Brest. As a result, German and Austro-Hungarian forces entered Ukraine to secure grain supplies and add Ukraine to Berlin and Vienna's sphere of influence. ${ }^{4}$ To the leaders of the UNR, these changes offered hope for the lifting of the Bolshevik occupation. Since 15 February, German forces - joined by Austro-Hungarians after

Холмщини, Підляшшя й Полісся', Калєндар-Альманах Дніпро, viii (1931), 81-6; Домет Олянчин, 'Спогади про культурно-освітню працю на Підляшшу, Поліссі й Волині в 1917 р.’, Аітопис Червоної Калини, іх, 1 (1937), 12-15.

${ }^{2}$ All dates are given according to the new style. UCR did not recognise Lenin's government (the Council of People's Commissars) as the legal government of Russia. Until January 1918, its position was that Russia should remain a democratic federation of equal nations, whose central powers would be established through agreements between all democratic forces involved.

${ }^{3}$ In late January and early February 1918 the control of UNR extended only to a fragment of Volhynia; the country's major hubs (including Kiev) and railway lines were held by Bolsheviks, who invaded Ukraine in January 1918. Bolshevik forces claimed to represent the People's Secretariat and Central Executive Committee of the Soviets of Ukraine, but were made up mostly of Soviet Russian troops. The proclamation of independence of the UNR was antedated to 22 January 1918.

${ }^{4}$ See Frank Golczewski, Deutsche und Ukrainer 1914-1939 (Paderborn, 2010), 246-9. 
28 February - advanced swiftly eastward, seizing control of all territories claimed by UNR by the end of April, and even reaching beyond to establish a perimeter at the Surazh-Rylsk-Sudzha-Belgorod-Valuyki line in the north-east and Millerovo-Novocherkassk-Rostov in the east, at the boundary of territories controlled by the Don Cossacks. German control extended over governorates of Kiev, Chernikhov, Kharkiv, and Poltava, a part of the Yekaterinoslav Governorate, most of the Volhynia Governorate, and the Taurida Governorate including Crimea. ${ }^{5}$ The Austrian occupation zone was commanded from Odessa and included the governorates of Podolia and Kherson, a part of the Yekaterinoslav Governorate, and a fragment of the Volhynia Governorate. Two key cities on the Black Sea coast, Mykolaiv and Odessa, housed mixed German-Austrian garrisons. ${ }^{6}$

Though Germany, Austro-Hungary, and Ukraine remained nominal allies on an equal footing, the German-Austrian presence resembled a de facto occupation. ${ }^{7}$ On 29 April a coup - inspired by Germany and conducted with German support - ousted the Ukrainian Central Rada and elevated General Pavlo Skoropadskyi to the position of the Hetman of the Ukrainian State. The period of the Hetmanate (29 April - 14 December 1918) remains one of the most controversial chapters in the history of Ukrainian national revolution. After 1921 its failure came to be interpreted in two distinct ways: one interpretation was advocated by the so-called Narodnik school subscribing to the ideology of UNR and of the Ukrainian left-wing nationalists; the other was put forward by the so-called Derzhavnyk school, which endorsed the

${ }^{5}$ German troops took Crimea in late April 1918, putting an end to the Socialist Soviet Republic of Taurida - a Bolshevik state governed by activists of the international Communist movement dispatched from Moscow. Subsequently, Germans established a Home Government led by General Suleyman Sulkevich (Polish: Maciej Sulkiewicz), a Lithuanian Tatar, and based mostly on the pre-revolutionary Russian elites. The question of the status of Crimea remained unresolved throughout the German presence in the east, but Germans rejected Ukraine's claim to the peninsula. See: Grzegorz Skrukwa, 'Crimea - the Ukrainian Point of View. History and the Present Time', Sensus Historiae. Studia Interdyscyplinarne, ii, 1 (2011), 135-54.

${ }^{6}$ For more, see: Włodzimierz Mędrzecki, Niemiecka interwencja militarna na Ukrainie w 1918 roku (Warszawa, 2000), 69-70.

${ }^{7}$ For documents regarding Austro-Hungarian policies for the Ukraine, see Theophil Hornykiewicz (ed.), Ereignisse in der Ukraine 1914-1922, deren Bedeutung und historische Hintergründe (4 vols., Philadelphia, 1966-9). 
Hetmanate. For the former, the Hetmanate was a pernicious parody of the Ukrainian state whose reactionary social policies disheartened the peasantry toward the Ukrainian national idea and fostered Bolshevik sympathies, while its limited achievements in the Ukrainisation of culture and education were nullified by the extensive presence and activity of Russian nationalists and imperialists within the Hetmanate's government apparatus. The Derzhavnyk school, on the other hand, saw the Hetmanate as an opportunity for the formation of an internally and externally stable Ukrainian state, wasted due to the intransigent opposition of the blinkered, doctrinaire left.

As a watershed, marking the proclamation of a fully independent Ukraine, the Treaty of Brest, the entrance of the forces of the Central Powers, and the rise and fall of the Hetmanate, the year 1918 figured extensively in many Ukrainian memoirs and journalistic accounts devised as contributions to the debate on the failed attempt to create an independent Ukraine which took place after 1920 among Ukrainians in Poland, Germany, Czechoslovakia, and other countries. Hetman Pavlo Skoropadskyi himself offered a personal account, as did the minister of foreign affairs for the Hetmanate, Dmytro Doroshenko, and the chief of the Ukrainian Telegraph Agency and later theoretician of radical Ukrainian nationalism, Dmytro Dontsov. ${ }^{8}$ German and Austro-Hungarian intervention forces are also mentioned in a number of other texts, including those written by the critics of the Hetmanate.

8 Павло Скоропадський, Спогади. Кінецьь 1917 - грудень 1918 (Kyiv and Philadelphia, 1995). This critical edition from 1995 includes the full text in its original shape in Russian, as written in 1919 in Berlin. Fragments were published in 1924-5. Pavlo Skoropadskyi (1873-1945) - General of the Russian Army, commander of the Ukrainian corps of the Russian Army in 1917. As an émigré in Germany in 1918-45, he became the centre of the Ukrainian monarchic movement. Дмитро Дорошенко, Мої спомини про недавне минуле (1914-1920 рр.) (Kyiv, 2007). Dmytro Doroshenko (1882-1951) - historian, activist of the Ukrainian national movement in the Russian Empire before the First World War, one of the leaders of the Ukrainian Party of Social-Federalists (a liberal centre-right formation) in 1917, Ukraine's minister of foreign affairs during the Hetmanate (20 May - 14 September 1918), since 1920 in emigration. Main proponent of the Derzhavnyk ('state') school of interpretation of the modern history of Ukraine. Дмитро Донцов, Рік 1918, Київ (Kyiv, 2002; Toronto, 1954¹). 


\section{I \\ THE PORTRAYAL OF THE ENTRANCE \\ OF THE FORCES OF THE CENTRAL POWERS \\ AND OF AN ENEMY BECOMING AN ALLY}

At the outset of the German presence in Ukraine, Ukrainian intelligentsia neither espoused a consistent anti-German programme nor expressed clear anti-German attitudes. Yet, as far back as 1917, most of the leaders of the Ukrainian national movement within the Russian Empire operated in a common Russian cultural and political sphere, for the most part sharing the convictions of the educated classes of Russia. Since the turn of the century, these classes have increasingly given in to Germanophobia inspired by the rising might of Germany and its expansionist tendencies, as well as the escalating hostility toward ethnic Germans within Russia. These attitudes peaked during the Great War, finding expression in the renaming of Saint Petersburg as Petrograd, the wholesale changing of German-sounding names, or the cloud of suspicion of espionage surrounding Empress Alexandra. Nothing indicates that the Ukrainian intellectuals who took part in the establishment of the UNR and the Ukrainian State after 1917 actively embraced anti-German sentiments. However, a vast majority of the Ukrainian intelligentsia remained loyal Russian subjects until 1917, albeit with a healthy dose of fatalism since the effective stifling of the Ukrainian national movement in Russia in 1914, and the persecution of the local, significantly more developed Ukrainian national movement in Galicia by the Russian occupation forces in 1914-15, designed to neutralise the 'Ukrainian Piedmont'. Still, the February Revolution fuelled hopes for a Russia remodelled as a democratic state of equal nations, and military units with significant Ukrainian contingents formed at that time proved more cohesive and valorous than those made up of a mixture of Russian subjects. Until 1917 the common view of Germans as enemies and aggressors was also shared by the so-called Little Russians or 'unconscious Ukrainians', members of the Ukrainian ethnos who were identified as Ukrainian on a regional or ethnographic level. The Union for the Liberation of Ukraine, an irredentist anti-Russian organisation aligned with Berlin and Vienna, had little sway inside the country. ${ }^{9}$ The attitudes of Ukrainian

${ }^{9}$ Oleh Fedyshyn, 'The Germans and the Union for the Liberation of the Ukraine, 1914-1917', in Taras Hunczak (ed.), The Ukraine, 1917-1921: A Study in Revolution 
intelligentsia toward Austria were made distinct by the fact that Ukrainians living under Austrian rule in Galicia enjoyed more favourable conditions than their counterparts in the Russian Empire in terms of linguistic, cultural, and political rights.

The Central Powers became formal allies of the UNR, and then of the Ukrainian State, on 9 February 1918. The German and AustroHungarian campaign, which scattered Bolshevik formations and removed them from Ukraine, received a positive assessment in all Ukrainian texts by non-Soviet authors, be it with a clear tendency to stress the key role and independence of Ukrainian formations. ${ }^{10}$ The image of German forces and their attitude toward Ukrainian statehood is always relatively positive:

During the initial stage of occupation of the Right-Bank Ukraine and Kiev both the German military and its leadership maintained healthy relations with the Ukrainian people and authorities. They did not interfere in the people's private lives, ensuring that the German army came to Ukraine as friends, intending to rid the country of Bolsheviks, help the Ukrainian nation achieve a peaceful life, bring order. ${ }^{11}$

The dominant emotions accompanying the entrance of the Germans in February 1918 were doubt, respect for their military might, discipline, and modern equipment, and - among middle and upper classes - hope for order and safety:

Two sensations mixed in everyone's mind. On the one hand, there was the certainty that all lawlessness, wildness, and cruelty will be no more, that people will no longer be subjected to inhuman treatment, ransacked, and robbed. On the other, there was an insecurity: no one knew what the unknown men who walked the streets in tight columns to the sound of the trumpet carried under their steel helmets. It was

(Cambridge MA, 1977), 305-22; Ю. П. Лавров, 'Початок діяльності Союзу Визволення України’, Український історичний журнал, 4 (1998), 17-32; Український історичний журнал, 5 (1998), 3-16; I. Г. Патер, 'Союз визволення України: заснування, політична платформа, інформаційно-дипломатична діяльність', in Олександр Реєнт (ed.), Велика Війна 1914-1918 рр. і Україна (Kуiv, 2014), 363-76.

${ }^{10}$ The German assessment identified Ukrainian involvement as symbolic; see Mędrzecki, Niemiecka interwencja, 63-4.

${ }^{11}$ Олександр І. Удовиченко, Україна у війні за державність. Історія організації і бойових дій Українських Збройних Сил 1917-1921 (Kyiv, 1995; Winnipeg, 1951¹), 31. The author was an officer of the Army of the UNR. 
clear that Ukrainians showed no enmity toward the Germans because they arrived as 'allies'. But even non-Ukrainians and common citizen in general gave them a hearty welcome in Kiev, as they brought salvation from the Bolshevik hell. ${ }^{12}$

A distinguished officer of the UNR army, Colonel Vsevolod Petriv graduate of a former imperial academy of the General Staff - member of the Ukrainian Party of Socialist Revolutionaries in 1917-19, described social attitudes in the following terms:

Russian intelligentsia firmly against Ukrainians, though some approve of the German intervention; Jewish, Ukrainian, and Russian bourgeoisie indifferent, even content; peasants do not oppose the Central Rada and support Ukraine, but fear social exploitation and rightist [counter] reform by Germans, even as leftist circles in the Central Rada ensure no [counter] reform would come. The workers are silent ... . ${ }^{13}$

However, participants in the Ukrainian national movement who spent the years 1914-17 in the Russian army often viewed Germans with persistent hostility - particularly if they had witnessed their inhuman conduct of war. Nykyfor Avramenko, officer of the Zaporizhia Division which cooperated with German forces in 1918, survived a German gas attack the year before, where he witnessed his comrades die from phosgene; for him, Germans were despicable and treacherous enemies. The shift in relations prompted him to respond in this manner: "It was a peculiar feeling to see Germans as friends. A year ago, there was Cherevyshche. That is not something one could ever forget ... Well! Now we need their aid and 'friendship'."14

The transformation of an enemy into an ally was a historic event in every way. Petriv recounted the first meeting with the Germans thus: "It is done. We have new allies. Those men in heavy iron helmets, with their heavy tread and those deathly litigious countenances, whom we, as soldiers of the Russian army, saw as our gravest

${ }^{12}$ Микола Галаган, 3 моїх споминів ... 1880-mi-1920-mi (Kyiv, 2005; L’viv, $\left.1930^{1}\right), 343$.

${ }^{13}$ Всеволод Петрів, 'Спомини з часів української революції (1917-1921)', in idem, Військово-історичні праці. Спомини (Kyiv, 2002; L’viv, 1929¹), 360-1.

${ }^{14}$ Никифор Авраменко, Спомини запорожия (Kyiv, 2007), 227. Cf. ibidem, 192-5 - the German gas attack on the position of the 40th Corps was conducted on 10 April 1917 near the village of Rudka Cherevyshche on the Stokhod river. 
enemies. Now those officers sit [opposite us] with the friendliest smiles manageable." 15

Attitudes toward the intervention forces took on a particularly complex shape within the Sich Riflemen, a formation composed primarily of Austrian subjects. ${ }^{16}$ Sich Riflemen formed under the banner of Galician independence from Austrian authorities, and could be seen as traitors and deserters in Austria. The 'official' history of the Sich Riflemen from 1937 includes the following statement: "German units closed in from Manevychi toward Sarny. The first Ukrainian troops they met were the same Sich Riflemen who had only recently dreamt of facing Germans in battle for the Ukrainian partition of the Austrian empire." 17 Yet, even here the initial stages of the German intervention are portrayed in a positive manner:

The German garrison brought complete stability to the capital, which soon began to resemble a central city in a major country. ... Small German units were sent even to provincial towns. After the recent disquiet, the society breathed a sigh of relief, returning to its everyday labours. Though the peasants' mute anxiety over the land was unaffected by the [entrance of the] Germans, they did not intrude upon local matters and acted in a very appropriate manner: they were merely finding their feet in a new conjuncture, just as the people were adjusting to their presence. ${ }^{18}$

Of the initial period of the German intervention, the conflict over Crimea drew a comparatively large amount of attention in later works

15 Петрів, 'Спомини', 344.

${ }^{16}$ Sich Riflemen - military formation of the Central Rada, initially formed mostly of Ukrainians from Galicia imprisoned by Russians during the Great War, in part of veterans of the Legion of Ukrainian Sich Riflemen (a volunteer formation serving in the Austro-Hungarian army). A unit of high morale and cohesion. The Regiment of Sich Riflemen was disarmed by Germans and disbanded after the coup that established the Hetmanate. In the summer of 1918 the Hetman accepted a request for Sich Riflemen to be recreated and stationed at Bila Tserkva, and in November the Riflemen revolted against him as the main fighting force of the anti-Hetmanate rebellion. Sich Riflemen supplied the leadership of the later Ukrainian Military Organisation and the Organisation of Ukrainian Nationalists: Yevhen Konovalets, Andriy Melnyk, Roman Sushko, and others. See Grzegorz Skrukwa, Formacje wojskowe ukraińskiej 'rewolucji narodowej' 1914-1921 (Toruń, 2008), 248-57.

17 Василь Кучабський, 'Від первопочинів до проскурівського періоду', in idem, Марко Безручко, and Свген Коновалець, Золоті ворота. Історія Січович Стрільизів 1917-1919 (L'viv, 2004), 63.

18 Ibidem, 65. 
by Ukrainian authors. In April 1918 UNR forces entered Crimea to seize the ships of the Black Sea Fleet, but were forced to withdraw by the Germans. The tension threatened to erupt in a UkrainianGerman conflict. In Ukrainian memoirs, the episode is painted in dramatic strokes, with German policies toward Crimea and the Fleet given a highly critical assessment. At the same time, though the local German command is said to have proved inflexible, its conduct is also described as honourable, and much of the blame for the failure of the Crimean expedition is laid at the feet of Ukrainian authorities in Kiev. ${ }^{19}$

II

GENERAL ASSESSMENT OF POLITICAL RELATIONS. VIEWS ON THE POLITICAL PROGRAMME OF THE OCCUPIER

During the inter-war period, Ukrainian commentators were convinced Germans had played a key role in the toppling of the Central Rada and the establishment of the Hetmanate. ${ }^{20}$ Skoropadskyi himself had left a record of his pre-coup consultations with the Germans. ${ }^{21}$ In their memoirs, Ukrainian politicians rarely speak of an 'occupation', but actual German hegemony is identified as a simple fact. In late spring and early summer, Dontsov expressed the conviction that the political situation in Ukraine is under total German control: if Germans wished so, they could depose the Hetman, change the Prime Minister, etc. In one of his notes, Dontsov replaced the word "Germans" with the periphrasis "masters of situation". ${ }^{22}$ Elsewhere, the word 'allies' was placed in quotation marks. ${ }^{23}$ In the entry for 15 October 1918 Dontsov made the following note about his conversation with the German Consul General, Fritz Thiel: "Very polite and courteous response. In principle - he accepts all. In practice - he accepts nothing at all. [Afterward] Thiel's mask slipped, exposing a 'man in power'." ${ }^{4}$

19 Петрів, 'Спомини', 522-34; Борис Монкевич, Почід Болбочана на Крим. Спогади сотника Армї УНР та його бойових побратимів (Куіv, 2014), 114-56; Авраменко, Спомини, 235.

${ }^{20}$ Галаган, 3 моїх споминів, 375.

${ }^{21}$ Скоропадський, Спогади, 147-8.

22 Донцов, Рік 1918, 50-3.

${ }^{23}$ Ibidem, 72.

${ }^{24}$ Ibidem, 106. 
The ambivalence of the Ukrainian right toward German presence in Ukraine is captured vividly in two sentences from Doroshenko's memoirs: "Under temporary protection from the German forces, we seek to erect a truly self-sufficient, strong Ukrainian state", and "Germans, who upheld the new regime in Ukraine, wanted to expand the scope of its exploitation." 25 Skoropadskyi expressed a similar ambivalence in direct terms:

My intercourse with Germans evoked in me feelings of great complexity. On the one hand, we needed them badly. Without them, Ukraine would have been what it has now become - a desert. On the other hand, their reign in Kiev brought me no true joy. I was thankful to them, but at the same time loathed them completely. ${ }^{26}$

Regardless of political affiliation, Ukrainian memoir-writers stressed the economic motivation of Germany's interest in Ukraine and noted the unequal relations between the two countries, which reduced Ukraine to the function of a semi-colony providing raw material and agricultural goods for the metropole. Skoropadskyi stated that the architects of German policy

saw Ukraine as a playground for their schemes. Not for no reason had they enlisted the aid of outstanding specialists in finances, industry, and trade; armed themselves in countless designs for new banks; established numerous associations for the exploitation of our wealth in Germany; or pressured our ministers for railway licences, etc. ${ }^{27}$

Doroshenko named short-term exploitation as the main reason for the entrance of German forces into Ukraine:

All the Germans wanted was to secure grain supplies in accordance with the Treaty of Brest, as it was precisely the demand for grain and the products of wealthy Ukraine in general that led them to sign the treaty in the first place. For the Central Powers, with their hungry populations, it was Brotfrieden in the full sense of the term. ${ }^{28}$

\footnotetext{
25 Дорошенко, Мої спомини, 254, 331.

${ }^{26}$ Скоропадський, Спогади, 146.

27 Ibidem, 246.

28 Дорошенко, Мої спомини, 237.
} 
In spite of all the unequal standing of the Ukrainian State and the German Reich, Doroshenko still described their negotiations over trade and monetary matters as a conversation between two formally equal partners. ${ }^{29}$

In political terms, Germany did not seem Ukraine's tried and true ally, and Berlin's multi-axial eastern policy loomed large. Dontsov noted his suspicion that Germany cooperated with Russian liberalnationalist Kadet party, a policy that could lead to the disowning of the Ukrainian state. ${ }^{30}$ Skoropadskyi, on the other hand, pointed to Germany's twofold policy toward the Bolshevik movement:

Germany's policy was simply dumbfounding: while they maintained close contact with the Bolshevik government in the north, they blocked all Bolshevik activity in our country, dealing ruthlessly with all Bolsheviks. ... The Kiev 'Oberkommando' was displeased with the policy of the central government and Grenner [sic] sent endless reports indicating the need for Germany to cut ties to Bolsheviks in the north, but the Berlin diplomats did not share his views. ${ }^{31}$

Doroshenko, incidentally a suspected Austrophile, left behind a separate, highly negative account of the Habsburg monarchy's policies toward Ukraine:

As Ukraine's immediate neighbour, Austria would gladly tear off a healthy bit of its territory, either by creating a special Ukrainian Kronland - as the late Archduke Ferdinand desired - or by binding it to an autonomous Poland under the Habsburg crown. But a hungering, gaunt Austria consumed by internal squabbles wanted peace more than anything. ... Handled by Hungarians, Austrian diplomacy was even less likely than its German counterpart to succumb to any form of 'Ukrainophilia'. ${ }^{32}$

Memoirs by authors who opposed the Hetmanate offer a generally negative assessment of the policies of the Central Powers, though their critiques were often aimed at Russian, pro-Russian, and reactionary forces active in the Ukrainian State, rather than Germans themselves. Mykola Halahan, department chief at the Ministry

\footnotetext{
${ }^{29}$ Ibidem, 331-3.

30 Донцов, Рік 1918, 61; ibidem, 100.

31 Скоропадський, Спогади, 142. “Grenner" - see below.

32 Дорошенко, Мої спомини, 280.
} 
of Health of the Hetmanate, wrote: "Thanks to the Germans, the heirs, factory owners, and financiers of the infamous 'Protofis' found themselves in command. The new order was really just the 'old regime' under a new name." ${ }^{33}$ At the same time, Halahan makes almost no mention of Germans elsewhere in his assessment of the period between summer and autumn of 1918, in spite of his highly critical view of the Hetmanate. ${ }^{34}$ This curious absence of the occupiers typifies many similar texts, such as the memoirs of Petro Yeroshevych, an officer of the Army of the Ukrainian State stationed at Vinnytsia. He paints a mostly negative portrait of the Hetmanate, recounting the anti-peasant repressions, Russification, and anti-Ukrainian attitudes of many figures appointed to high ranks within the army and the administration, as well as the social climate of speculation and corruption that marked the year $1918 .{ }^{35}$ Germans are only mentioned when the author learns of transports of Ukrainian chernozem to Germany, a shocking piece of news that he views as an abomination far worse than such 'normal exploitation' as the extraction of grain or sugar. ${ }^{36}$

The image and assessment of the intervention by the Central Powers put forward by authors related to the Sich Riflemen is decidedly critical - due not only to the personal threat of repressions which most members of this formation would face from the Austrian authorities, but also to its unequivocally leftist attitudes. At the time of publication of the 'official' history of the Rifles, however, the veterans of the unit had already moved toward the so-called

${ }^{33}$ Галаган, 3 моїх споминів, 378. 'Protofis' - Union of Industry, Trade, Finance, and Agriculture, an organisation representing big money, one of the pillars of the Hetmanate.

${ }^{34}$ Ibidem, 374-97. Only when relating the collapse of the Hetmanate does Halahan indicate German involvement in defending the regime, in part in a mercenary role.

35 Петро Срошевич, '3 боротьби українського народу за свою незалежність', 3а Державність, viii (1938), 18-23. See also below.

${ }^{36}$ Ibidem, 17. A similar absence of the intervention forces in memoirs of the period of the Hetmanate written from a rural perspective: С. Левченко, 'Інструкторська Школа Старшин', За Державність, viii (1938), 120-39 - Germans are only mentioned once, when the author observes German troops during a drill and admires their fitness (ibidem, 126); idem, '8-й Катеринославський корпус', За Державність, ix (1939), 60-75; Іван Вислоцький, '16 місяців у рядах київських Січович Стрільців’, Аітопис Червоної Калини, vii, 7-8 (1935). 
integral nationalism. ${ }^{37}$ Still, the veterans could hardly erase their own biographies, within which the toppling of the Hetman figured as a major heroic feat. Integral nationalism promoted the idea that nations should pursue independence on their own, without depending on the benevolence of major powers; the Rifles had also kept faith with the concept of social justice inherited from the revolution. Both at the time and in later years, the pro-Russian attitude of the Hetmanate remained its discrediting feature in the eyes of the Rifles. Hence descriptions of German policies in the spring of 1918 include accusations of imperialism, instrumental treatment of the Ukrainian question, and establishment of an anti-social Hetmanate. ${ }^{38}$ Similar opinions are expressed in a monograph on Ukrainian military history published in L'viv; the chapter on the twentieth century was edited by veterans of the Sich Riflemen, the Ukrainian Galician Army, and the Army of the UNR:

Having just set foot on Ukrainian soil, German and Austrian troops took on the air of conquerors. The German military command interfered in Ukraine's internal politics, conducted mass requisitions of food, illegally arrested Ukrainian citizen. ... German command cooperated with nonUkrainian bourgeoisie and the landed gentry to depose the Central Rada and institute a government suited to its own requirements. ${ }^{39}$

These publications decried the violation of Ukrainian sovereignty by the order on seeding, given by the commander-in-chief of the German forces, Field Marshal Hermann von Eichhorn, on 6 April 1918, which created the possibility for landowners to regain their property, and even to introduce forced labour for their benefit. ${ }^{40}$ Attention was also drawn to the institution of German court-martial and the disarmament of the so-called Blue Division (the Cossack Volunteer Division),

37 Кучабський, Безручко, and Коновалець, Золоті ворота.

38 Кучабський, ‘Від первопочинів’, 73-4; Іван Андрух, ‘Січові Стрільці в корпусі ген. Натіїва', Аітопис Червоної Кахини, ii, 4 (1930), 8; Ivan Andrukh (1892-1921) - an officer of the Sich Riflemen; Роман Дашкевич, 'Про Січових Стрільців', in Галина Сварник and Андрій Фелонюк (eds.), Олена Степанів - Роман дашкевич. Cnоzади і нариси (L'viv, 2009), 348. Roman Dashkevych (1892-1975) - an officer of the Sich Riflemen, later an activist of the Ukrainian youth movement in inter-war Poland.

${ }^{39}$ Іван Крипякевич et al., Історія украӥнського війська (L'viv, 1992), 156.

${ }^{40}$ More in Mędrzecki, Niemiecka interwencja, 140-1. 
formed in Germany of Ukrainian prisoners of war from the Russian Army - a unit Germans found to be too leftist. ${ }^{41}$

A pamphlet written by the first Prime Minister of the UNR, Volodymyr Vynnychenko, occupies a special place in the Ukrainian discourse on the German intervention. ${ }^{42} \mathrm{~A}$ while later, in 1919-20, Vynnychenko unsuccessfully lobbied for a compromise between the Ukrainian leftist nationalists and Soviet Russia, and the 1920 pamphlet discrediting the policies of the leaders of the UNR was designed to serve that purpose. Of all writings to come from UNR politicians, it proposes the most negative appraisal of the intervention, treated not as a necessary evil, but as evil in itself - a symptom of German imperialism in political, class, and social context ("of a class of German capitalists and Junkers represented by the military might commanded by the German general staff"). ${ }^{43}$ The cooperation between the Central Rada and Germany simply testified to the 'petit bourgeois' outlook of the former. ${ }^{44}$

III

COMMON AND INDIVIDUAL FEATURES

OF THE INTERVENTION FORCES

Skoropadskyi offered a rather extensive analysis of the make-up of particular structures of German Reich present in Ukraine. At the same time, what it boils down to is a set of schemes typical for the worldview of a conservative landowning officer - honourable soldiers, nimble diplomats, crooked speculators, big-headed scientists:

Those of the military class who came here were honest with no exception. The highest command did not engage in any speculation, personally

41 Seе: Олександр Вишнівський, 'До історії Синіх і Залізних', За Державність, vii (1937), 68-9; Skrukwa, Formacje wojskowe, 276-82; Golczewski, Deutsche und Ukrainer, 282-91.

42 Volodymyr Vynnychenko (1880-1951) - writer and journalist, leader of the Ukrainian Social-Democratic Party of Workers, Prime Minister of UNR (20 Nov. 1917 - 30 Jan. 1918). One of the leaders of the anti-Hetmanate rebellion in November 1918, President of the Directorate since 13 November 1918 until 10 February 1919. In 1919-20, he fruitlessly promoted an agreement between UNR and the Bolsheviks.

43 Володимир Винниченко, Відродження націï, ii (Kyiv and Vienna, 1920), 305. See also ibidem, 208-11, 317-20.

${ }^{44}$ Ibidem, 202-4, 303-6, 320-8. 
discouraged from it, and in political terms, all those Eichhorns, Grenners [sic], and their closest aides simply expected the Treaty of Brest to be implemented, viewing all further demands as excessive. They had a soft spot for Ukraine and would never want to see her economy crumple - on the contrary, they offered help to prevent that. As far as their beliefs were concerned, they were democrats, especially Grenner. ... Lower-rank commanders did not engage in politics and were a mixed crowd, but all fulfilled their duties and were honest men. This continued until the autumn. ${ }^{45}$

The diplomats, as is their wont, adapted to the situation, initially looking to their ministry of foreign affairs, the emperor and his circle, then to the Reichstag, and finally to socialists. The politics changed every step of the way, uncertain .... ${ }^{46}$

Germany's big companies and businessmen were followed by lots of scum of various kinds, simply put: hungry jackals who sowed ill to all of us and, plainly speaking - though this does not affect me - to Germans themselves. Here, those people were joined by numerous activists of the same ilk. The speculators concocted a colossal stew, as the German jackals moved with unimaginable swiftness, constantly repeating the phrase "our government expects this", etc.

There was also the class of scientists, scholars in various fields, and journalists. As far as those learned men are concerned, I, a person raised in deep respect for German science, found myself slightly disillusioned with them once we became more familiar. Since they view themselves as men of science, I thought that one should expect of them to show deeper thinking and the ability to assess facts rightly. Indeed, there was nothing of the sort - only the pursuit of cheap rewards, demagoguery, theoretical flair, and group conviction in their own superiority. ${ }^{47}$

Within memoirs of Ukrainian activists who spent the period of the Hetmanate in Kiev and encountered the highest officials and civilian representatives of Germany, attempted portrayals of the latter - at times extending into broader considerations on Germany's politics played an important part. Skoropadskyi offered an unequivocally positive assessment of Eichhorn, and remembered the attempt on his

${ }^{45}$ Скоропадський, Спогади, 245-6. Hermann von Eichhorn (1848-1918) - commander of Army Group Kiev (Heeresgruppe Kiew), highest German military commander in Ukraine. Gen. Wilhelm Groener (1867-1939) - chief of staff of Army Group Kiev until 28 October 1918, subsequently successor to Erich Ludendorff as quartermaster general. Skoropadskyi inaccurately transcribes his name into Cyrillic as "Grenner".

${ }^{46}$ Ibidem, 246.

${ }^{47}$ Ibidem, 247. 
life, perpetrated on 30 July 1918 by the underground party of Leftist Social-Revolutionaries (a branch of Russian S-R's cooperating with Bolsheviks), with indignation and pain:

The venerable old man, intelligent, highly educated, broad-minded, kindhearted - not for nothing was he the grandson of the philosopher Schelling. He was completely untainted by the arrogance and conceit which sometimes marked German officers. ... An intelligent, far-sighted, incorruptible man. He arrived in Ukraine with an army and could very well demand more than Germany had - few would not have done so in his place - for we were entirely powerless, especially during the initial period; conversely, he had always offered great understanding and support in all situations where the actions of particular figures or units contravened our interests ... ${ }^{48}$

The Hetman also painted a positive image of Wilhelm Groener, in spite of the fact that the latter had communicated to him Germany's objection to plans for the formation of a Ukrainian army:

Our personal relations were good. I never saw him to seek private gains, which sadly could not be said of many of his subordinates. ... In political and national matters, he shared my view that the efforts of Ukrainians [alone] would not suffice to erect a state. I knew I was dealing with the chief of staff of an army that came here with a purpose; in any case, this was a decent and kind man of broad political views and undisputed integrity - so much so, that he did not shirk from criticising Germany's political game with the Bolsheviks in my presence. ${ }^{49}$

Meanwhile, the other German commander-in-chief, General Karl Kirchbach, earned only brief and negative remarks due to his supposed involvement in a dictatorial shift in German policy, which turned Ukraine into a de facto protectorate:

Throughout [the preceding period] he sat in Vilnius, in occupied country, throwing his weight about in disregard of local authorities. I observed that Germans were seizing control over aspects of life thus far thought beyond their mandate, a fact borne out by a letter I had received, in which General Grenner [sic] demanded, under orders of Count Kirbach [sic], that all bills of high importance be presented to him for acceptance prior to the vote. ${ }^{50}$

${ }^{48}$ Ibidem, 171, 244. Eichhorn was indeed a grandson of Friedrich Schelling.

${ }^{49}$ Ibidem, 191.

${ }^{50}$ Ibidem, 271. 
The Hetman spoke critically of those officers who leaned toward what he perceived as inappropriate political tendencies, whether from the left or from the right. Captain Konstantin von Alvensleben was named a spokesman for the landowning circles seeking unconditional restitution of the pre-revolutionary social status quo. ${ }^{51}$ Colonel Maximilian von Stolzenberg, on the other hand, was branded as a proponent of Ukrainian hard-line nationalism with ties to politicians from the Central Rada. ${ }^{52}$

Doroshenko's testimony is far more critical of the highest German officials:

Field Marshal Eichhorn, privately an amiable man, open and simple as a soldier. However, the actual 'politics' was conducted not by Eichhorn himself, but by his chief of staff, General Groener. A highly talented and gifted man, though not particularly moral; highly invested in his own career ... . Groener (like all German officials in Ukraine in general) did not see Ukraine as a part of any broad, far-reaching plans or political ploys, but simply as an interlude of solely strategic importance. His attitude toward Ukrainians and Ukrainian political activists was coloured by barely covered contempt. ${ }^{53}$

The disparity between the views of the Hetman and those of his minister of foreign affairs is also manifest in their account of German diplomats. While the Hetman praised them, Doroshenko disagreed:

I have to admit that I enjoyed working with Baron von Mumm. In himself, he was a good man, already visibly weary of the service, delighting in honours, susceptible to flattery, an old bachelor with a strong sentimental streak. ... His deputy, von Berchem, a sharper fellow with good education and intelligence ... . To me, he was sincere and decent to the last. The main unknown among the diplomats was Consul General Thiel, who had served for 25 years in Japan and knew nothing of Ukraine, but, thanks to his intelligence and knowledge, dealt well with complex matters and adapted to us fairly quickly. Some went so far as to accuse him of Bolshevism - utter nonsense. ${ }^{54}$

${ }^{51}$ Ibidem, 149. Nb. Dmytro Doroshenko also criticised Alvensleben, who attempted to block Doroshenko's nomination due to his 'Austrophilia' (Дорошенко, Мої спомини, 266).

${ }^{52}$ Скоропадський, Спогади, 190.

53 Дорошенко, Мої спомини, 265.

${ }^{54}$ Скоропадський, Спогади, 246. Alfons Mumm von Schwarzenstein (1859-1924) - German diplomat, ambassador of the German Reich in Kiev 9 March - 4 November 
There was little to distinguish between Groener and the civilian representatives - Deputy Mumm and Councillor Count Berken [sic].... The German government seemed to make a point of dispatching to Kiev men who had no knowledge of or interest in Ukraine and who looked down on Ukrainian statehood. Mumm, an old and worldly man, could hold his own, but Count Berken's disposition became unpleasant and brutal. ${ }^{55}$

Disparities between Skoropadskyi and Doroshenko also extend to their assessment of the ambassador of Austro-Hungary, Johann von Forgach. Here, the views expressed are mutually contradictory in factual terms - for the Hetman, Forgach was too pro-Ukrainian, while for Doroshenko, he was a conscious enemy of the Ukrainian national idea.

Among Austrians, Count Forgatch [sic] was hailed as a foremost diplomat, which explains his deployment to Ukraine. Obviously, he knew his work well and showed exceptional sensitivity in his demeanour, while still being firm and ruthless. It was he who told me that they hated him so much in Serbia that called every dog in Belgrade a Forgatch. Our relations were cautious. ... He hated Russia and showed interest in Ukraine only as a possible playground for Austrian politics and maybe, if the game went in Austria's favour, as a fourth [sic] country of the Austrian empire ... . He maintained constant relations with Ukrainian chauvinists - all government nominations that failed to meet their expectations, all official decisions taken by a person suspected of not being a radical chauvinist, were immediately reported to Forgatch, and he - in his roundabout and exceptionally sensitive, but consistent manner - relayed them to me. ${ }^{56}$

Count Johann Forgatch [sic] was a die-hard enemy of Slavs in general, and of the Ukrainian identity in particular. In Kiev, he lived with a certain aristocratic family (which he knew since his previous appointment to Petersburg), where the anti-Ukrainian crowd commonly met, and read Kievskaya Mysl avidly (while consistently hiding his knowledge of Russian), meaning that the Austrian ambassador was always duly 'informed' and, as a result, inimical to the cause of the Ukrainian nation and state. ${ }^{57}$

Among memoirs written from other perspectives, Colonel Petriv's views on the German army command a certain attention. During

1918. Johannes von Berchem - deputy ambassador, acting ambassador since October 1918.

55 Дорошенко, Мої спомини, 266.

${ }^{56}$ Скоропадський, Спогади, 240-1.

57 Дорошенко, Мої спомини, 280. 
a common campaign against Bolshevik forces in Eastern Ukraine in the spring of 1918, Petriv mostly met the German cavalry. As a confirmed leftist, he offers a dispassionate account of the monarchical and conservative world-view of German officers of higher ranks, describing it as narrow-minded in spite of their intellectual faculties and military virtues. ${ }^{58}$

\section{IV}

\section{EVERYDAY RELATIONS WITH THE OCCUPYING FORCES}

According to Doroshenko, before the coup that established the Hetmanate, everyday relations between Ukrainian nationalist circles and the Germans were too cold. For him, this was one of discrediting features of Ukrainian leftist elites, who proved themselves lacking in diplomatic sense and political culture:

In Ukraine's official circles, Germans were greeted coldly, as occupiers, not allies. No one sought any rapprochement, casual meetings, or information. ... Meanwhile, Russian, Jewish, and Polish circles did all they could to reinforce their ties with Germans, to inform them - and one can imagine what they had to say about Ukraine and its young statehood! The uncommon coolness and stiffness, a personal trademark of Prof. Hrushevsky ..., seemed to set the tone for relations between the Ukrainian government and officials, and the Germans - servicemen, civilians, officials, journalists - who had been coming to Kiev. No welcome, no meetings, and no contact outside of purely official matters. ${ }^{59}$

In the accounts of Ukrainian officials of the Hetmanate, their relations with German servicemen and diplomats do not seem to extend beyond the normal sociability and courtesy. Official functions were organised for the Germans, who also visited theatres. ${ }^{60}$ Dontsov describes a dinner party he threw for German scientists in the name of the Ukrainian Party of Democrats - Khliboroby. ${ }^{61} \mathrm{He}$ also mentions other meetings and conversations with German and Austrian scholars and

58 Петрів, Військово-історичні, 463-4.

${ }^{59}$ Дорошенко, Мої спомини, 234. Mykhailo Hrushevsky (1866-1934) - leading Ukrainian historian of the first half of the twentieth century, president of the Ukrainian Central Council.

${ }^{60}$ Скоропадський, Спогади, 191; Донцов, Рік 1918, 42, 45, 102, 110.

61 Донцов, Рік 1918, 93. 
journalists arriving to Ukraine. ${ }^{62}$ Obviously, maintaining relations with the German press was among his professional duties as the director of the press agency, and his background as a former antiRussian émigré who had spent the years 1914-16 establishing connections in Berlin marks him out from the rest of the Kiev scene. Interestingly, Dontsov regularly uses German words in his diary, which serves to underline the sense of the moment while reflecting his German experience. However, members of the opposition also maintained political relations with German diplomats and servicemen: 'taking a walk' to Eichhorn or Groener was common practice. ${ }^{63}$

The social climate of speculation and corruption characteristic of the period of the Hetmanate is commonly described, even by the Hetman himself. ${ }^{64}$ In 1918, high numbers of refugees from the upper and middle classes of Russia proper migrated into Ukraine - a group composed as much of the high society as of the demi-monde. The laxity of wartime and occupation made prosperity easier to achieve thanks to speculation; at the same time, it was commonly thought that these fortunes were fleeting and uncertain. Gambling, prostitution, corruption, drunkenness, and consumption of luxurious goods were strikingly prevalent in public life in both Kiev and Odessa, as well as smaller cities. In general, Ukrainian memoirs did not name Germans among the participants in this "scum bath". However, Dontsov included Germans in his subtly critical image of the beau monde of the time:

May 30. ... Evening in a box at the opera. Offenbach's 'Beautiful Helen'. (German representative) Mumm sat below with his crowd. When I saw the stalls awash in electric light, heard the vulgar jokes of shameless clowns on stage, and compared that to the tragic reality, I was reminded of 'The last years of the Commonwealth' by Kostomarov or 'The year 1793' by Reymont. ${ }^{65}$

62 Ibidem, 81, 86, 90, 110.

${ }^{63}$ Ibidem, 50-1.

${ }^{64}$ Скоропадський, Спогади, 226.

65 Донцов, Рік 1918, 42. 'The last years of the Commonwealth' - a study by Ukrainian historian Mykola Kostomarov (1817-93) devoted to the decline of prepartition Poland, published 1869-70; it includes a negative assessment of the Polish aristocracy of the period. 'The year 1793' - actually 'The Year 1794', is a novel by Polish writer Władysław Reymont (1876-1925, 1924 Nobel Prize laureate), a critical portrayal of the moral decline of Polish pro-Russian aristocrats of pre-partition Poland during the Russian occupation before the Kościuszko Uprising. 
Memoirs by servicemen put forward a fairly complex account of relations with the Germans, if the latter are mentioned at all. Petriv describes his dealings with the German army during the common campaign against Bolsheviks in Left-Bank Ukraine in the spring of 1918 as rich in courtesy, even fraternal, involving the exchange of sabres, the sharing of songs, and the raising of toasts: "Hoch die ukrainische Reiterei!" (by the Germans) or "Für tapfere deutsche Reiterei!" (by the Ukrainians). Drinks permitted even a gentlemanly reverence in remembrances of the battles that saw today's comrades fight on opposite sides in 1917. ${ }^{66}$ Still, Petriv's account also mentions certain blunders. One German general, for instance, introduced Lieutenant Prince von Hessen as "a kinsman of Your empress", forcing Petriv to recount that, though Alice of Hessen (Alexandra, the wife of Nicholas II) was indeed the empress of an army he used to serve in, Ukraine was not under imperial rule. The Germans kept their composure, responding in conciliatory tones that, as servicemen, they were unfamiliar with Ukrainian matters. ${ }^{67}$ Seeing that the Regiment of Mounted Haidamaks under Petriv's command included one Shtakelberg, an officer of German extraction, the German general offered by way of a compliment that the presence of a member of an ancient knightly house of Livonia proved that the Ukrainian cause was just; Shtakelberg, who identified as Ukrainian, apparently responded coolly in Ukrainian. ${ }^{68}$

Relations between Ukrainian and German units at a later stage (summer and autumn of 1918) are given a dramatically different slant by Ivan Andrukh, an officer of the Sich Riflemen. He writes that the German policy of ruthless exploitation of rural Ukraine evoked such hatred that any solitary Germans who met the Sich Riflemen or the soldiers of the Zaporizhia Corps was killed immediately. For their part, Germans supposedly perceived the Ukrainian army as "the scum of the earth." 69

\footnotetext{
${ }^{66}$ Петрів, Військово-історичні, 432-8, 460-3.

67 Ibidem, 432.

68 Ibidem, 437.

${ }^{69}$ Андрух, 'Січові Стрільці', 8.
} 


\section{$\mathrm{V}$ \\ THE TREATMENT OF THE PEOPLE OF UKRAINE BY THE INTERVENTION FORCES}

The memoirs of Skoropadskyi, Doroshenko, and Dontsov clearly consider the situation from the perspective of Kiev, since neither of the authors resided in the country during the Hetmanate. The repression and exploitation of the country that historians now identify as key features of German and Austrian intervention policies may be mentioned, but in a rather detached and abstract manner:

Germans, and Austrians even more so, implemented policies that were destined to antagonise the people of Ukraine. I repeatedly asked General Grenner [sic] to consider devising a system that would ensure the isolation of German troops from the populace, leaving to us the responsibility for supplying the German army with whatever it required. Of course, we faced many obstacles, as our administration was not yet organised. ${ }^{70}$

Doroshenko saw the intervention forces as collaborators, enforcers, or amicable spectators of reactionary terror, rather than its main initiators:

Polish landowners in Volhynia and Podolia set the tone by directly asking Austrian authorities to occupy Right-Bank Ukraine, introduce its own government, and enforce redress - by payment or through labour - of damages incurred from the peasantry. ... Just as landowners from Volhynia and Podolia, our compatriots from Left-Bank Ukraine and the steppes would go straight to German or Austrian command and demand that peasants be put down. The illegal collection of 'contributions' from the peasants by spontaneously organised armed units (with tacit approval from Germans and Austrians) began in earnest under the regime of the Central Rada. ${ }^{71}$

The same question is discussed in sharper tones by authors critical of the Hetmanate in general who spent the period of its rule in rural Ukraine. Petriv recalls stories told by peasants, of villages pacified already during the late spring of 1918, or of sham requisitions; one peasant remembered being handed a receipt inscribed with "Bei einem Schwein habe ich ein Schwein bekommen" ("I obtained one swine from another swine"). ${ }^{72}$ In his view, the responsibility for these ills

\footnotetext{
70 Скоропадський, Спогади, 184.

71 Дорошенко, Мої спомини, 326.

72 Петрів, Військово-історичні, 579.
} 
lay with private punitive formations of the landowners, rather than the Germans. Petriv also describes the peasant revolts of 1918 and the German involvement in the quelling. ${ }^{73}$ Descriptions of pacifications by Germans and Austrians can be found in other memoirs and popular historical accounts. ${ }^{74}$

Yurko Tyutyunnyk described the triumphalism of peasant rebels who managed to disarm a local German unit near Zvenyhorodka in the summer of 1918. Even he, though, lays the blame for anti-peasant repressions primarily with the private armies of the landowners. While the local German command is said to consistently cooperate with the landowners, imprisoned German soldiers are depicted with compassion and called, not without a dose of irony, "kamarads" (from the German "Kameraden" - comrades). ${ }^{75}$

\section{VI}

\section{COMPARING THE TWO INTERVENTION FORCES}

Ukrainian memoirs consistently describe the Austro-Hungarian intervention in less sympathetic tones than its German counterpart. ${ }^{76}$ The Hetman himself lent several highly critical passages to the conduct of the Austrians:

The Austrians repeatedly implied that one could expect more benevolence from them than from the Germans. In fact, though, to put it in simple

${ }^{73}$ Ibidem, 586-91.

${ }^{74}$ Михайло Михайлик, 'Українське село в часи націон. революції', Аітопис Червоної Калини, vi, 1 (1934), 14; Федір Мелешко, 'Глодоси в часі національної революції, Аітопис Червоної Калини, vi, 7-8 (1934), 22.

${ }^{75}$ Юрко Тютюнник, 'Революційна стихія', in idem, Революційна стихія, Зимовий noxid 1919-1920 рр., Спомини (L'viv, 2004), 62-8. Yurko Tyutyunnyk (1891-1929) - an activist of the Ukrainian Party of Social-Revolutionaries, peasant rebel leader, subsequently general of the Army of UNR.

${ }^{76}$ The arrival of the Legion of Ukrainian Sich Riflemen in Ukraine (near Elizavetgrad) and the presence of Archduke Wilhelm Habsburg (named Vasyl Vyshyvanyi), the subject of monarchic designs competing with Skoropadskyi's Hetmanate, in its ranks constitutes another chapter in the history of the AustroHungarian intervention. See: Крипякевич et al., Iсторія, 189-91; Skrukwa, Formacje wojskowe, 108-12, 272-4; Ю. Терещенко and Т. Осташко, Український патріот з династіі Габсбургів (Kyiv, 2008), 30-49; Timothy Snyder, The Red Prince: The Secret Lives of a Habsburg Archduke (New York, 2008), 100-11; Golczewski, Deutsche und Ukrainer, 271-82. 
terms, my own relations with Germans were simpler and more consistent than those I had with Austrians. The 'Oberkommando' went out of its way to help us in everything; the Austrians spoke softly, but did God only knows what. ... The German army was infinitely more organised and less likely to sack the populace, while the Austrians excelled in the opposite to an unthinkable degree. ... For them, sacking was simply legal, and nothing I told the Austrian representatives could ever change that. Corruption and fraud achieved colossal levels in their ranks. ... The cruelties of the Austrian army greatly exceeded all the Germans were at fault for, without the order, and even the command was too consumed in speculation to act. They allowed themselves unacceptable liberties; for instance, an Austrian general once caused a controversy by claiming the authority to grant some Armenian-Jewish company fishing rights, including the illegal use of trawl. Similar instances of overreach happened everywhere. ${ }^{77}$

Doroshenko's views are almost identical:

The Austrian military administration in the Yekaterinoslav, Kherson, and Podolia districts provided us with a broad selection of reasons to complain. The motley crew that was the Austrian army, already deeply demoralised, became a thorn in the side of the populace. Austrians quelled the peasant revolts in the summer of 1918 with brutality. On the pretence of fighting 'Bolsheviks', they repeatedly arrested and imprisoned Ukrainian national activists. ${ }^{78}$

The Austro-Hungarian army in Ukraine included a rather limited number of Ukrainians since the marching battalions of East Galician regiments were mostly dispatched to the Italian Front. One of the few officers of Ukrainian extraction in the Imperial and Royal forces in Ukraine was Stepan Shukhevych, commander of military police in Odessa and a Ukrainian national activist. ${ }^{79}$ His account of the Austrian forces in Ukraine is critical, as well. In his view, the military police was in the hands of Hungarians, for whom the expedition to Ukraine was a trip to a wheeler-dealer's El Dorado:

There were very good, good, bad, and very bad commissions. Among the best were commissions in Ukraine; among the worst - those in Albania and on the Italian Front. Ukraine was the best because one could plunder,

77 Скоропадський, Спогади, 171-2, 184, and 240.

78 Дорошенко, Мої спомини, 280-1.

${ }^{79}$ Stepan Shukhevych (1877-1945) - lawyer, co-organiser of the Legion of Ukrainian Sich Riflemen and an officer in the unit 1914-15, subsequently an officer of Austria's regular army, in 1918-20 an officer of Ukrainian Galician Army. 
steal, cheat - gain a fortune. Albania was the worst for the malaria; the Italian Front is self-explanatory. ${ }^{80}$

Another Ukrainian officer in the Austrian army, named Bekesevych, remembers how he, as commander of the Haisyn train station, and Colonel Sponder (presumably German), commander of the regiment stationed in the city, attempted to spare members of the Ukrainian opposition from repression by administrators from the Hetmanate. ${ }^{81}$

\section{VII \\ EVACUATION}

The anti-Hetmanate rebellion and the restitution of the UNR correlated with the defeat of the Central Powers, the dissolution of Austro-Hungary, and the conclusion of the Great War. German and Austro-Hungarian troops evacuated to their homelands until the early 1919. In Ukrainian memoirs, the retreat of the forces of Central Powers is generally described in neutral terms. ${ }^{82}$ The Hetman proposed an all too simplistic notion that the German army "crumbled after the fashion of the Russian Army." 83 Petriv's recollection of a monthlong stay in Kiev besieged by the rebels includes only marginal mentions of Germans. ${ }^{84}$ Shukhevych briefly notes the dawdling and demoralisation of Austro-Hungarian troops, while maintaining that German units remained cohesive and disciplined to the last. ${ }^{85}$ In his memoirs, Bekesevych paints a similar portrait of the last days of occupation in Podolia. ${ }^{86}$

Dontsov remembers his farewell with Berchem (literally) packing his bags. ${ }^{87} \mathrm{He}$ also ironically comments on the disparity between the aspirations and possibilities of German politics in late 1918:

80 Степан Шухевич, Моє життя. Спогади (London, 1991), 253.

${ }^{81}$ П. Бекесевич, 'Мої спомини $з$ останніх днів окупації України австро-німецькими військами’, Аітопис Червоної Калини, iii, 3 (1931), 4.

82 Дорошенко, Мої спомини, 382-90.

83 Скоропадський, Спогади, 308.

${ }^{84}$ Петрів, Військово-історичні, 607-23.

${ }^{85}$ Степан Шухевич, Спомини з Украйнськоӥ-Галицьької Армї̈ (1918-1920) (L'viv, 1929), 8-11.

${ }^{86}$ Бекесевич, 'Мої спомини', 6.

87 Донцов, Рік 1918, 124. 
November 19. Dinner at the Grand Hotel. I saw Dirksen and Thiel. ... They told me that Germans would be neutral in the civil war that is now breaking out in Ukraine, but will not stand for lawlessness and chaos. Mumm's deputy did not explain how one would wage a civil war without violating law and order. ${ }^{88}$

\section{CONCLUSION}

In Ukrainian memoirs, the German and Austrian intervention in Ukraine is typically described as a necessary evil, even by the Hetman and Ukrainian politicians supporting the Hetmanate. The aims of German policy for Ukraine are generally and unequivocally identified as exploitative, and the treatment of the Ukrainian cause as more or less instrumental. However, for the Ukrainian republican left, the intervention of the Central Powers becomes the setting for the regime of the Hetman, injurious for the Ukrainian national and social cause, rather than an ill in itself. In spite of many critical observations, particularly regarding agricultural policies, Ukrainian non-Soviet memoirs and popular histories still view Germans and Austrians in more positive terms than other external forces partaking in the complex and multifaceted conflict in Ukraine. It was not forgotten that, the occupation notwithstanding, in 1918 Ukraine became subject to international law recognised by the Central Powers - Germany, Austro-Hungary, Turkey, and Bulgaria - as well as the defeated former members of the Entente, Soviet Russia and Romania. Comparisons between the French intervention in 1919 and its German counterpart in Ukrainian memory typically come out significantly in favour of the latter precisely due to the formal acceptance of Ukraine's equal standing, as well as a more tactful conduct during negotiations. ${ }^{89}$

88 Ibidem, 117.

${ }^{89}$ During negotiations with Ukrainians in Odessa in January 1919, the French acted in an arrogant and dictatorial manner, as if they were in their own overseas colony, as many observers noted. This was a shock for the Ukrainian left, which had great admiration for France and the Entente as a whole. Vynnychenko's view that "the brutal German generals were the image of tact and gentlemanly conduct compared to those "knights"' (Винниченко, Відродження, ii, 257), is one-sided - at the time Vynnychenko lobbied for a compromise with Bolsheviks against the entire Entente and discredited pro-western politicians and commanders in the UNR. Yet, the image of the colonial manners of the French is also found in other Ukrainian sources. See Skrukwa, Formacje wojskowe, 376-8. 
This combined with explicit or implicit sympathies for inter-war Germany as the state that questioned the Versailles agreement which did not leave any room for an independent Ukraine.

trans. Antoni Górny

\section{SELECTED BIBLIOGRAPHY}

Андрух Іван, 'Січові Стрільці в корпусі ген. Натіїва', Аітопис Червоної Калини, iі, 4-5 (1930), 5-5; 15-18.

Авраменко Никифор, Спомини запорожия (Kуiv, 2007).

Бекесевич П., 'Мої спомини з останніх днів окупації України австро-німецькими військами', Літопис Червоної Калини, іii, 3 (1931), 4-6.

Донцов Дмитро, Рік 1918, Киӥв (Kуiv, 2002²).

Дорошенко Дмитро, Мої спомини про недавнє минуле (1914-1920рр.) (Kуiv, 2007). Ерошевич Петро, ‘3 боротьби українського народу за свою незалежність', За Державність, viii (1938), 9-65.

Golczewski Franz, Deutsche und Ukrainer 1914-1939 (Paderborn, 2010).

Гаген Марк фон [Hagen Mark von], “"У війнах творяться нації: націотворення в Україні під час Першої світової війни', in Каппелер Андреас [Kappeler Andreas] (ed.), Україна: процеси націотворення (Kyiv, 2011), 271-84.

Галаган Микола, 3 мойх споминів ... 1880-mi-1920-mi (Kyiv, 2005).

Hornykiewicz Theophil (ed.), Ereignisse in der Ukraine 1914-1922, deren Bedeutung und historische Hintergründe (4 vols., Philadelphia, 1966-9).

Hunczak Taras (ed.), The Ukraine, 1917-1921: A Study in Revolution (Cambridge MA, 1977).

Крипякевич Іван et al., Історія украӥнського війська (L'viv, 1992³).

Кучабський Василь, Безручко Марко, and Коновалець Євген, Золоті ворота. Icmoрія Січович Стрільців 1917-1919 (L’viv and Rochester, 2004³).

Куровський Вол[одимир], 'На окупованич Німцями землях Холмщини, Підляшшя й Полісся’, Календар-Альманах Дніпро, viii (1931), 81-6.

Лавров Ю. П., 'Початок діяльності Союзу Визволення України', Украйнський історичний журнал, 4-5 (1998), 17-32; 3-16.

Левченко С., 'Інструкторська Школа Старшин', За Державність, viii (1938), 119-39.

Левченко С., '8-й Катеринославський корпус', За Державність, ix (1939), 60-75.

Mędrzecki Włodzimierz, Niemiecka interwencja militarna na Ukrainie w 1918 roku (Warszawa, 2000).

Мелешко Федір, 'Глодоси в часі національної революції, Аітопис Червоної Калини, vi, 7-8 (1934), 20-4.

Михайлик Михайло, 'Українське село в часи націон. революції', Аітопис Червоної Калини, vi, 1-2 (1934), 10-14; 5-9.

Монкевич Борис, Похід Болбочана на Крим. Спогади сотника Армї̈ уНР та його бойових побратимів (Kyiv, 2014²).

Олянчин Домет, 'Спогади про культурно-освітню працю на Підляшшу, Поліссі й Волині в 1917 р.’, Аітопис Червоної Кахини, іх, 1 (1937), 12-15. 
Петрів Всеволод, Військово-історичні праціі. Спомини (Kуіv, 2002).

Реєнт Олександр and Сердюк Олександр, Периа світова війна і Україна (Kуiv, 2004).

Реєнт Олександр (еd.), Велика Війна 1914-1918 рр. і Україна (Куіv 2014).

Skrukwa Grzegorz, 'Crimea - the Ukrainian Point of View. History and the Present Time', Sensus Historiae. Studia Interdyscyplinarne, ii, 1 (2011), 135-54.

Skrukwa Grzegorz, Formacje wojskowe ukraińskiej 'rewolucji narodowej' 1914-1921 (Toruń, 2008).

Скоропадський Павло, Спогади. Кінецьь 1917 - грудень 1918 (Kyiv and Philadelphia, 1995).

Snyder Timothy, The Red Prince: The Secret Lives of a Habsburg Archduke (New York, 2008).

Шухевич Степан, Спомини з Українськоӥ-Гахицької Армії (1918-1920) (L'viv, 1929). Шухевич Степан, Мое життя. Спогади (London, 1991).

Терещенко Ю. and Осташко Т., Український патріот з династіi Габсбургів (Kуiv, 2008).

Тютюнник Юрко, Революційна стихія, Зимовий похід 1919-1920 рр., Спомини (L'viv, 2004).

Винниченко Володимир, Віәродження нації, ii (Kyiv and Vienna, 1920).

Вислоцький Іван, '16 місяців у рядах київськич Січович Стрільців', Аітопис Червоної Калини, vii, 7-8 (1935), 29-34.

Вишнівський Олександр, ‘До історії Синіх і Залізних’, За Державність, vii (1937), 68-101.

Удовиченко Олександр І., Украйна у війні за державність. Історія організації і бойових дій Українських Збройних Сил 1917-1921 (Kyiv, 1995).

Yekelchyk Serhii, Ukraine: Birth of a Modern Nation (Oxford, 2007).

Grzegorz Skrukwa - 20th century history; assistant professor at the Institute of Eastern Studies, Adam Mickiewicz University, Poznań; e-mail: skrukwa@amu. edu.pl 